\title{
STUDI LEMBAGA FILANTROPI MEDIA MASSA
}

\author{
Muhammad Aiz \\ Dosen STIT Al Marhalah Al Ulya Bekasi \\ aiz@almarhalah.ac.id
}

\begin{abstract}
The strong effect of civil society in Indonesia causing practice of philantrophy is dominated by Non of Goverment Organization. This article agrees with Azyumardi Azra stating since period of Indonesian archipelago, this issue become a less of intervention from ruler. Moreover it can be proved there a numbers of philantrophy institutions either traditionalist or civil society organization up to mass media company followed it. The positive effect can be seen by a lot of group community intiating to manage of Philantrophy. On the contrary, it caused of negative effect that Philantrophy is not unorganized transparently and still weak for the accountability. This research uses sociology history approaches that may applied on related Philanthropy.
\end{abstract}

Key Words: Philantrophy; Mass media; Poverty; Natural Disaster

\begin{abstract}
Abstrak
Kuatnya pengaruh kelompok masyarakat sipil (civil society) di Indonesia menyebabkan praktik filantropi masih didominasi oleh pihak non negara. Artikel ini sesuai dengan pendapat Azyumardi Azra yang menyatakan sejak masa kesultanan di Nusantara, persoalan filantropi memang minim campur tangan penguasa. Kenyataan tersebut dapat dibuktikan pula banyaknya lembaga-lembaga filantropi, baik yang bersifat tradisional, organisasi masyarakat sipil, hingga perusahaan media massa yang ikut mengurusi urusan filantropi. Hal ini tidak hanya berimplikasi positif yakni dengan munculnya berbagai kelompok masyarakat yang berinisiatif untuk mengelola filantropi. Namun di sisi lain menyebabkan implikasi yang negatif juga seperti belum terkelolanya potensi filantropi secara transaparan dan akuntabilitasnya pun masih rendah. Pendekatan yang digunakan dalam artikel ini adalah pendekatan historis sosiologis.
\end{abstract}

Kata Kunci: filantropi; media massa; kemiskinan; bencana alam 


\section{A. Pendahuluan}

Pada bulan September 2019, jumlah penduduk miskin (penduduk dengan pengeluaran per kapita per bulan di bawah garis kemiskinan) di Indonesia mencapai 24,79 juta orang $(9,22$ persen), berkurang sebesar 0,36 juta orang dibandingkan dengan penduduk miskin pada Maret 2019. Prosentase penduduk miskin perkotaan periode Maret 2019 sebesar 6,69\% , turun menjadi $6,56 \%$ di bulan September 2019. Adapun di daerah perdesaan pada periode Maret 2019 sebesar 12,58\% dan turun menjadi 12,60\% di bulan September 2019. ${ }^{1}$

Tingginya angka kemiskinan di negara Indonesia menuntut adanya berbagai inovasi untuk memaksimalkan filantropi, khususnya dalam ajaran Islam. Rendahnya inovasi yang dilakukan oleh lembaga pengelola Ziswa (zakat, infak, sedekah, dan wakaf) ${ }^{2}$ menjadi salah satu penyebab masih belum tergalinya potensi filantropi di Indonesia. Konsep persaudaraan antara sesama muslim nampaknya baru dipahami sebatas ajaran dan belum dijadikan sebagai pedoman hidup umat muslim.

Pentingnya inovasi dalam memaksimalkan filantropi di zaman modern ini menjadi sebuah keharusan untuk mewujudkan keadilan. ${ }^{3}$ Inovasi dalam filantropi sesungguhnya bukan hal baru. $^{4}$

\footnotetext{
${ }^{1}$ http://www.bps.go.id, diakses 9 Januari 2020.

${ }^{2}$ Sebagian peneliti dan pelaku filantropi berpendapat bahwa zakat bukan tergolong filantropi karena sifatnya yang obligatory. Namun, sebagian berpendapat zakat merupakan bagian dari kegiatan filanntropi karena penyalurannya tidak diatur dalam hukum formal, tidak dipaksakan dan tidak ada konsekuensi hukuman bagi yang tidak menjalankannya.Lihat, http://ditpolkom.bappenas.go.id, diakses, 4 Juni 2015.

${ }^{3}$ Badan Wakaf Indonesia,KAPF, IRTI, Manajemen Wakaf di Era Modern (Jakarta: Badan Wakaf Indonesia, 2013), 3.

${ }^{4}$ Pada tanggal 7 Juli 1964 diberitakan dalam surat kabar Lisan al-Hal terbitan Beirut dan al-Akhbar al-Misriyyah telah ditemukannya 300 dokumen kuno yang tertulis dengan tinta emas di kantor wakaf Mesir. Dokumen tersebut berkaitan dengan wakaf yang di dalam prakteknya saat itu telah mengalami perkembangan sesuai dengan corak pemikiran masyarakat saat itu. Diantaranya adalah wakaf untuk kepentingan peniupan dupa ketika dilakukan pengajian, seorang perempuan yang mewakafkan harta berupa tali timba untuk kepentingan pengambilan airdi masjid. Lihat, Muhammad Jawad Mughniyah, Fiqih Lima Mazhab (Jakarta: Lentera, 2008), 678-679.
} 
Seperti inovasi tentang wakaf uang ${ }^{5}$, wakaf berjangka waktu $^{6}$, dan wakaf Hak atas Kekayaan Intelektual (HaKI). ${ }^{7}$ Konsep filantropi di negara Indonesia sesungguhnya telah mengalami berbagai perubahan jika dilihat dari peraturan perundang-undangan tentang wakaf ${ }^{8}$ yang pernah ada atau saat ini sedang berlaku. Perubahan ini termasuk juga dalam persoalan referensi mazhab yang dipakai dalam peraturan perundangundangan tersebut ${ }^{9}$ yang dapat mengakomodir inovasi dalam pengembangan wakaf produktif.

5 Magda Ismail Abdel Mohsin, "Financing Through Cash-Waqf:a Revitalization to Finance Different Needs", International Journal of Islamic and Middle Eastern Finance and Management, Vol. 6 No. 4, 2013, 306. Di masa Rasulallah wakaf uang belum dikenal. Wakaf uang baru dipraktekkan di abad kedua Hijriyah. Diriwayatkan oleh Imam Bukhari bahwa Imam al-Zuhri (wafat $124 \mathrm{H}$ ), salah seorang ulama terkemuka dan peletak dasar tadwin al hadith, memberikan fatwanya untuk berwakaf dengan Dinar dan Dirham agar dapat dimanfaatkan sebagai sarana pembangunan, dakwah, sosial, dan pendidikan umat Islam. Cara yang dilakukan adalah dengan menjadikan uang tersebut sebagai modal usaha (modal produktif) kemudian menyalurkan keuntungannya sebagai wakaf. Lihat, http://www.pesantrenvirtual.com. diakses, 8 Januari 2014.

${ }^{6}$ Mazhab Maliki berpendapat bahwa harta benda yang diwakafkan oleh wakif tetap menjadi milik wakif, namun tidak tidak dibenarkan melakukan sesuatu atas benda yang diwakafkan tersebut. Hal ini yang dipahami dengan wakaf berjangka. Lihat, Yasir Abdul Karim al Haurani, al-Waqf wa al-'Amal al-Ahli fi al-Mujtama' al-Islami Case: Jordan (Kuwait, Kuwait Awqaf Public Foundation, 2001), 15.

${ }^{7}$ Ada perbedaan penggunaan istilah, ada yang menggunakan istilah hak milik intelektual, dan hak kekayaan intelektual. Demikian juga dengan penulisan singkatannya, ada yang menulis HMI, HAKI, dan HaKI. Lihat, OK Saidin, Aspek Hukum Kekayaan Intelektual (Jakarta: Raja Grafindo Persada, 2003), 11.

${ }^{8}$ Peraturan tentang wakaf di Indonesia telah ada sejak sebelum kemerdekaan, yaitu tahun 1905. lihat, Direktorat Jenderal Bimbingan Masyarakat Islam dan Penyelenggaraan Haji, Pedoman Pengelolaan \& Pengembangan Wakaf (Jakarta:Dirjen Bimas Haji,2003), 21. Lihat juga perbedaan antara pasal 215 Kompilasi Hukum Islam yang menyatakan bahwa wakaf harus permanen dan pasal 1 UU Wakaf yang menyatakan kebolehan wakaf berjangka waktu.

${ }^{9}$ Risdianto, "Kebebasan Bermazhab Dalam Hukum Islam: Studi Terhadap UU No.41/2004 tentang Wakaf", Disertasi, UIN Syarif Hadiyatullah Jakarta, 2014), 29. 


\section{B. Sejarah Filantropi di Indonesia}

Istilah filantropi (philanthropy) berasal dari bahasa Yunani, philos (cinta) dan anthropos (manusia), yang secara harfiah diartikan sebagai konseptualisasi dari praktik memberi (giving), pelayanan (service) dan asosiasi (association) dengan sukarela untuk membantu pihak lain yang membutuhkan sebagai ekspresi rasa cinta. Secara umum didefinisikan sebagai tindakan sukarela untuk kepentingan publik (voluntary action for the public goods). ${ }^{10}$

Filantropi (kedermawanan sosial) mungkin tergolong kata yang baru dan asing bagi sebagian besar masyarakat Indonesia. Namun, praktek kedermawanan sendiri sudah dikenal dan menjadi bagian kehidupan masyarakat nusantara. Beberapa kajian menunjukkan bahwa kegiatan filantropi sudah dipraktekkan sejak ratusan tahun yang lalu. Hal ini bisa diketahui dari ditemuinya praktek filanntropi sebagian bagian dari tradisi masyarakat di berbagai suku yang tersebar di daerah di Indonesia. Filantropi juga menjadi bagian dari ajaran dari berbagai agama dan kepercayaan yang ada di Indonesia. ${ }^{11}$

Dalam Islam, kata filantropi merupakan istilah baru yang tidak dikenal di awal penyebaran agama Islam. Namun saat ini bermunculan padanan kata dalam bahasa Arab untuk kata “filantropi" tersebut, seperti al-'ata' al-ijtima'i (pemberian sosial), al-takaful al-insani (solidaritas kemanusiaan), 'ata khayri (pemberian untuk kebaikan), al-birr (perbuatan baik) serta sadaqah (sedekah). ${ }^{12}$

10 Andi Agung Prihatna (2005). "Filantropi dan Keadilan Sosial di Indonesia". dalam Chaider S. Bamualim dan Irfan Abubakar, Revitalisasi Filantropi Islam: Studi Kasus Lembaga Zakat dan Wakaf di Indonesia (Jakarta, CSRC, 2007), 3-4. Lihat juga, Tanim Laila, "Innovations in Islamic Philantrophy and Monetization of Islamic Philantrophic Instruments", Institute of Hazrat Mohammad Saw, t.t, 1.

${ }^{11}$ Parvanova, D. (2013). Book Review: Fauzia, A. Faith and the State: A History of Islamic philanthropy in Indonesia. ASEAS-Austrian Journal of South-East Asian Studies, 6 (2), 2013, 398-401.

12 Barbara Ibrahim, From Charity to Social Change: Trends in Arab Philanthropy (Kairo: American University in Cairo Press, 2008), 11. 
Filantropi Islam berkembang di Indonesia bersamaan dengan hadirnya Islam. Praktik ini lebih mudah diterima oleh masyarakat di wilayah Nusantara karena bentuk-bentuk filantropi telah menjadi tradisi mereka terutama filantropi yang berakar pada ajaran agama. Meskipun demikian, penghimpunan serta pendistribusian materi yang bersumber dari kegiatan filantropi tersebut tidak dikelola oleh penguasa di masa kesultanan Islam. ${ }^{1}$

Naskah-naskah tentang islamisasi Nusantara terhadap nilai-nilai filantropi Islam tentu membawa perubahan pada masyarakat Nusantara, dan zakat berperan besar di sini, karena walau bagaimanapun juga, tampaknya masyarakat Nusantara mengharapkan bahwa Islam akan dapat mengubah masyarakat sedikit demi sedikit dibandingkan ketika mereka masih menyembah berhala. Memang tidaklah berlebihan bila dikatakan bahwa Islam banyak membawa perubahan pada masyarakat di Nusantara. Sebagai contoh, kontrol sosial sebagai manifestasi nilai-nilai keislaman di Nusantara tertuang dalam teks Tajul Salatin. ${ }^{14}$

Dalam salah satu babnya, teks tersebut tertulis penuh celaan terhadap orang-orang bakhil dan pujian bagi orang yang mau bermurah hati. "Hendaklah yang raja itu melebih hormat akan segala fakir dan miskin dan dimuliakan mereka itu terlebih daripada segala orang kaya dan harus senantiasa duduk dengan mereka itu...". Semangat egalitarianisme di atas belum sepenuhnya bisa dilakukan, terlebih lagi di kalangan elite kerajaan. Dalam adat raja-raja Melayu, sedekah dan zakat yang dikeluarkan oleh raja kepada fakir dan miskin diberikan pada saat diadakan upacara kerajaan seperti upacara kelahiran, upacara memotong rambut, dan upacara membayar nazar. Sedekah yang dikeluarkan raja pun tidak tanggung-tanggung, yaitu berupa emas, perak, dan pakaian kepada fakir miskin di seluruh negeri. Sedekah dan zakat yang diberikan raja dipakai sebagai alat melanggengkan kekuasaannya. Dalam kasus Nusantara, zakat merupakan suatu anasir penting dari tata hukum yang ada, baik hukum positif ataupun moralitas umum yang disosialisasikan melalui teks-teks bernafaskan Islam.

${ }^{13}$ Azyumardi Azra, "Filantropi dalam Sejarah Islam di Indonesia", dalam Zakat dan Peran Negara, ed. Kuntarno Noor Afiah dan Mohd. Nasir Tajang, (Jakarta: Forum Zakat, 2006), 17.

${ }^{14}$ Amelia Fauzia dan Ary Hermawan, "Ketegangan Antara Kekuasaan dan Aspek Normatif Filantrofi Dalam Sejarah Islam Indonesia", dalam Buku Berderma Untuk Semua (Jakarta: Mizan, t.t),159. 
Dalam masyarakat Jawa, misalnya, dikenal tradisi jimpitan, sebuah praktek kedermawanan yang dilakukan kaum perempuan dengan menyisihkan beras yang akan dimasak untuk disumbangkan bagi kegiatan sosial lingkungan atau disumbangkan kepada warga yang mendapatkan musibah. ${ }^{15}$ Tradisi serupa juga ditemui di masyarakat Sunda dengan nama yang berbeda, yakni Perelek. ${ }^{16}$

Selain jimpitan, Masyarakat Jawa juga mengenal tradisi maleman, megengan dan kupatan, sebuah tradisi bertukar atau mengirim makanan untuk kerabat, handai taulan dan khususnya untuk orang-orang tidak mampu di sekitar lingkungan yang dilaksanakan setiap menjelang bulan puasa, menjelang lebaran dan setelah lebaran.

Sementara masyarakat Toraja mempraktikkan tradisi bua bungaran, yakni mendermakan hasil panen tanaman atau ternak pertama pada desa atau lembaga sosial. Tradisi serupa juga dipraktikkan di Masyarakat Dayak. Sedangkan Masyarakat Bali mengenal dan mempraktikan tradisi Ngayah dalam kehidupan sehari-hari mereka. Ngayah bagi masyarakat Bali adalah tindakan kolektif ikhlas tanpa pamrih untuk tujuan kepentingan umum dan agama di Bali.

Konsep ini mirip dengan tradisi gotong royong di Jawa, namun secara khusus ngayah lebih pada sebuah pengabdian atau pemberian untuk tujuan keagamaan, kemasyarakatan, atau pada masa aristokrasi sebagai bentuk kesetiaan. Tradisi-tradisi semacam itu masih berakar kuat dan dipraktikkan di berbagai daerah di Indonesia.

Praktek filantropi juga menjadi bagian dari ajaran dan kegiatan keagamaan di Indonesia. Dalam Agama Islam yang dianut mayoritas penduduk Indonesia, misalnya, ditemukan konsep dan praktek filantropi dalam bentuk zakat, infak, sedekah, wakaf dan jenis pemberian lainnya.

15 Eka Nofianti, V. Indah Sri Pinasti, Puji Lestari, "Kohesi Sosial dalam Tradisi Jimpitan Beras pada Masyarakat Perdesaan (Studi Kasus Di RT 01 RW 02 Desa Kemiri Lor, Kecamatan Kemiri, Kabupaten Purworejo)", ESOCIETAS, Volume 3, Number 2, Tahun 2014.,www.journal.student.uny.ac.id, diakses, 4 Juni 2015.

16 R. H. Sumardhani, "Revitalisasi Semangat Ethnic Philanthropy", Humanitas, Vol. 1 No.1, Juli-Desember 2008, 12, http://digilib.unpas.ac.id, diakses, 4 Juni 2015. 
Konsep serupa juga ditemukan dalam ajaran Kristen, Katolik maupun protestan, dalam bentuk Kolekte, Persepuluhan, Dana Puasa Pembangunan, dan lain-lain. Sedangkan dalam ajaran agama Hindu dan Budha dikenal dan dipraktekkan Dana Punia, Dharma, dan sebagainya. Sebagian dari kegiatan filantropi yang berkaitan dengan ajaran keagamaan itu bersifat wajib (obligatory) dan sebagian lainnya bersifat pemberian suka rela (voluntary) yang didorong dan dianjurkan dalam rangka tolong-menolong, kerjasama,muamalah, hubungan antarmanusia. ${ }^{17}$

Dalam perkembangan filantropi di Indonesia, setidaknya terdapat 3 kategorisasi dari berbagai bentuk kegiatan filantropi. ${ }^{18}$ Bentuk yang pertama adalah filantropi tradisional, yaitu kegiatan filantropi yang berbasis pada tradisi dan ajaran agama yang diyakini oleh masyarakat Indonesia. Bentuk ini setidaknya menjadi pemicu munculnya serta berkembangnya filantropi di Indonesia. Hal ini dapat dipahami karena pada dasarnya sebagian besar pelaku filantropi berkeyakinan bahwa perilaku untuk berderma merupakan perintah agama dan akan mendapatkan pahala di sisi Tuhan YME Allah Swt. Keyakinan akan mendapatkan pahala inilah yang menjadi pendorong utama terhadap perilaku berderma. Suatu perilaku yang pada hakikatnya sangat mulia, dimana ada keterpanggilan jiwa untuk menyantuni atau setidaknya ikut membantu meringankan beban masyarakat yang tengah kesulitan, sebagaimana dalam hadis, sebagai berikut:

${ }^{17}$ Helmut K.Anheier dan Regina A.List, A Dictionary of Civil Society, Philanthropy and the Non-Profit Sector (London-New York: Routledge: 2005), 196.

${ }^{18}$ Saidi, Zaim, Mohammad Fuad dan Hamid Abidin, Praktik Filantropi Keadilan Sosial di Indonesia: Studi kasus lima CSRO (Civil Society Resource Organization) (Jakarta: PIRAC, 2006). 


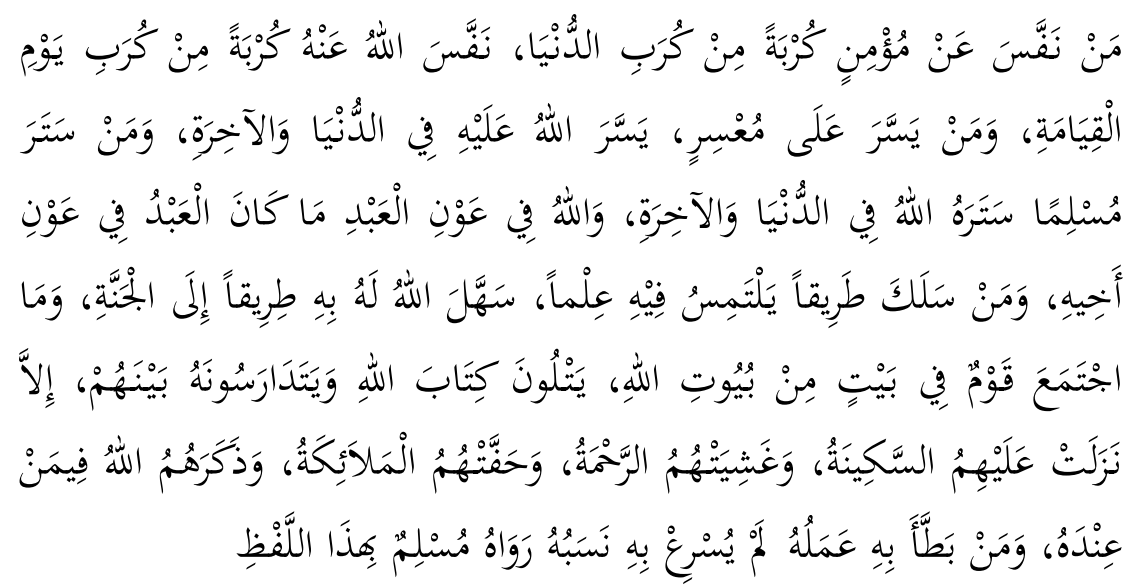

Artinya: Hadis diriwayatkan oleh al-lmam Muslim dengan lafaz ini. Dari Abu Hurairah r.a. daripada Nabi Saw, Baginda telah bersabda:Barangsiapa yang melepaskan seorang mu'min daripada satu kesusahan daripada kesusahan-kesusahan dunia, niscaya Allah akan melepaskannya daripada satu kesusahan daripada kesusahan-kesusahan kiamat. Barangsiapa yang mempermudahkan bagi orang susah, niscaya Allah akan mempermudahkan baginya di dunia dan di akhirat. Barangsiapa yang menutup ke'aiban seorang muslim, niscaya Allah akan menutup ke'aibannya di dunia dan akhirat. Allah sentiasa bersedia menolong hamba-Nya selagi mana dia suka menolong saudaranya. Barangsiapa yang melalui suatu jalan untuk menuntut ilmu, nescaya Allah akan mempermudahkan baginya suatu jalan menuju ke surga. Sesuatu kaum tidak berkumpul di salah sebuah rumah-rumah Allah (yaitu masjid) sambil mereka membaca kitab Allah dan mengkajinya sesama mereka melainkan suasana ketenangan akan turun ke atas mereka, rahmat akan melitupi mereka dan mereka akan di kelilingi oleh para malaikat dan Allah akan menyebut (perihal) mereka kepada orang-orang yang berada di sisi-Nya. Barangsiapa yang terlambat amalannya, niscaya nasab keturunannya tidak mampu mempercepatkannya.

Bentuk yang kedua, adalah kegiatan filantropi yang dilakukan oleh organisasi masyarakat sipil. Dalam konteks Indonesia, kelahiran organisasi masyarakat sipil di bidang amal keagamaan ini dilatarbelakangi stidaknya oleh munculnya krisis ekonomi dan krisis politik. 
Organisasi masyarakat sipil ini muncul sebagai bentuk respon atas "kegagalan" negara dalam melayani seluruh kebutuhan warga masyarakatnya untuk meningkatkan kesejahteraan sosial. Dengan adanya krisis tersebut maka muncul kesadaran untuk melakukan gerakan menggalang dana dari masyarakat yang bersumber dari zakat, infak sedekah, dan wakaf.

Pada tahun 1970-an mulai muncul dan berkembang organisasi masyarakat sipil di Indonesia. Kemunculan organisasiorganisasi ini menandai babak baru bagi perkembangan filantropi Indonesia. Organisasi-organisasi ini lahir sebagai respon atas munculnya masalah-masalah sosial baru sebagai dampak dari proses modernisasi negara Indonesia. Pembangunan yang berkembang saat itu sebagai bentuk dari proses modernisasi Indonesia telah memunculkan problem-problem kekinian yang tidak ditemui sebelumnya, seperti problem lingkungan, konsumen, buruh, HAM, dan persoalan sosial lainnya. Problemproblem ini menuntut pendekatan berbeda yang tidak dilakukan oleh filantropi tradisional.

Organisasi masyarakat sipil yang lahir pada saat itu menawarkan program-program dan pendekatan baru untuk menangani masalah-masalah ini. Program-program yang mereka tawarkan tidak hanya melalui pendekatan penyantunan dan pelayanan sosial, seperti yang banyak dilakukan oleh pelaku filantropi konvensional, tapi juga program-program advokasi. Gagasan-gagasan tentang partisipasi dan pemberdayaan rakyat, tentang advokasi, kebebasan, dan hak asasi, merupakan tema atau isu yang banyak diangkat. Berbeda dengan program-program karitatif dan keagamaan yang banyak didukung oleh filantropi konvensional, program-program organisasi masyarakat sipil ini tak banyak mendapatkan dukungan dari masyarakat, lembaga sosial maupun lembaga keagamaan. Karena itulah mereka mencoba mendanai program-program ini dengan menggalang dukungan pendanaan dari lembaga-lembaga donor internasional. Dalam perkebangannya dukungan dari lembaga donor ini menjadi sumber utama bagi program-program yang dijalankan oleh organisasi masyarakat sipil di Indonesia. ${ }^{19}$

\footnotetext{
${ }^{19} \mathrm{http} / / /$ ditpolkom.bappenas.go.id.
} 
Gerakan filantropi di Indonesia mengalami perkembangan yang cukup signifikan terutama setelah rezim Presiden Soeharto. Hal tersebut disebabkan adanya iklim politik yang lebih terbuka sehingga lebih memungkinkan masyarakat sipil dapat menyalurkan "kreativitas" nya dalam membantu masyarakat lainnya. Keinginan kuat untuk membantu sesama anggota masyarakat yang membutuhkan ini dipertajam dengan adanya bencana-bencana alam di Indonesia. Diantara organisasi masyarakat sipil yang bergerak di bidang filantropi adalah Dompet Dhuafa (Republika), Rumah Zakat, LazisNU, Lazis MU, Dewan Da'wah Infaq Club, Bulan Sabit Merah Indonesia, dan Pos Keadilan Peduli Umat (PKPU). ${ }^{20}$

Bentuk yang ketiga adalah organisasi sumber daya masyarakat sipil. Organisasi ini adalah bentukan masyarakat non pemerintah yng bersifat nirlaba yang didikelola, dan digerakkan secara lokal. ${ }^{21}$ Selain memobilisasi dana dari luar dan dalam negeri untuk mendanai program-programnnya, organisasi ini juga menyalurkannya kepada organisasi-organisasi masyarakat sipil dan kelompok-kelompok lain lewat pemberian dana atau mekanisme keuangan yang lain. Mereka menjalankan fungsi baru yang selama ini tak banyak dlakukan organisasi masyarakat sipil di Indonesia dan berpotensi menjadi lembaga grant making lokal. ${ }^{22}$ Sebagian dari organisasi ini, khususnya organisasi yang didirikan perusahaan dan keluarga kaya,cenderung mendanai progam-program filantropi tradisional dalam bentuk penyediaan pelayanan masyarakat seperti pendidikan dan kesehatan. Sementara organisasi sejenis lainnya yang digerakkan oleh para aktivis LSM mencoba memobilisasi dan menerima dana dari berbagai sumber untuk mendanai tidak hanya program-program penyediaan pelayanan sosial, tetapi juga program-program yang berusaha memecahkan berbagai persoalan yang timbul dari proses modernisasi tersebut di atas.

\footnotetext{
${ }^{20}$ http://interfidei.or.id.

21 Rustam Ibrahim, "National Directory of Civil Society Resource Organizations: Indonesia" (Jakarta: TheSynergos Institute, 2002).

${ }_{22}$ Grantmaking adalah skema penyaluran dana hibah dari kedua jenis foudation tersebut, bagi lembaga nonprofit/organisasi nirlaba. Untuk apa? Dana hibah tersebut disalurkan guna mendukung upaya-upaya yang dilakukan oleh organisasi nirlaba di bidang keagamaan, budaya, sosial, lingkungan dan kemanusiaan. Lihat http://keuanganlsm.com.
} 
Dari segi program, perkembangan filantropi Indonesia juga diwarnai dengan perluasan program yang ditawarkan kepada masyarakat untuk didukung dan disumbang. Di tengah maraknya kegiatan penggalangan dana untuk kegiatan keagamaan dan bencana, yang menjadi mainstream utama filantropi Indonesia, beberapa organisasi mulai mencoba mengarahkan kegiatan filantropi untuk mendukung-isu-isu yang sifatnya strategis dan bersifat jangka panjang.

Upaya ini dilakukan dengan memobilisasi dana dan daya dari masyarakat untuk program-program yang selama ini mendapatkan dukungan pendanaan dari lembaga donor. Misalnya, beberapa organisasi perempuan yang selama ini mendapatkan dukungan dari lembaga donor, mulai memobilisasi dana dari public dan korporate untuk mendukung program pemberdayaan perempuan. Melalui program "Peduli Perempuan" dan "Pundi Perempuan", mereka mencoba mengkampanyekan persoalan-persoalan perempuan, seperti kekerasan, trafficking, kesetaraan gender dan minimnya akses terhadap kesehatan reproduksi, agar didukung dan disumbang masyarakat. ${ }^{23}$

Beberapa kelompok lainnya, mengkampanyekan dukungan pendanaan terhadap program perlindungan konsumen, program anti korupsi, bantuan hukum bagi masyarakat miskin dan perlindungan buruh migran. Inisiatif-inisiatif semacam ini belum banyak dilakukan di tahun-tahun sebelumnya. Kecenderungan lain yang muncul dalam perkembangan filantropi di Indonesia dalam 10 tahun terakhir adalah upaya sinergi dan kolaborasi antar lembaga. Kolaborasi ini tidak hanya terjadi antar LSM, seperti yang selama ini banyak dilakukan, tapi juga antara LSM dengan OPZ dan perusahaan. Misalnya, enam organisasi yang concern terhadap isu perempuan (Jurnal Perempuan, Puan Amal Hayati, Mitra Inti, YSIK, Rifka Annisa dan PIRAC) berkolaborasi dalam jaringan Peduli Perempuan untuk berkampanye dan menggalang dana bagi program-program pemberdayaan perempuan.

\footnotetext{
${ }^{23}$ http://www.esensi.co.id, diakses, 2 Juni 2015.
} 
Dompet Dhuafa Republika juga bersinergi dengan YLKI dan PFI untuk menggalang sumbangan bagi perlindungan konsumen dari makanan bermelamin. DDR juga bersinergi dengan ICW dan YAPPIKA untuk mengkampanyekan program antikorupsi di sekolah dan dengan YLBHI untuk menggalang sumbangan bagi program bantuan hukum bagi rakyat miskin. Sinergi dan kolaborasi ini lebih dikarena masing-masing organisasi nirlaba mulai menyadari kelebihan dan kelemahan masing-masing. Mereka juga mulai menyadari bahwa isu-isu besar yang bersifat strategis tidak mungkin bisa diatasi dengan bekerja sendiri-sendiri. Dengan kolaborasi ini, masing-masing bisa belajar dan saling menutupi kelemahan masing-masing.

\section{Filantropi Media Massa}

Perkembangan filantropi di era 1990-an juga ditandai dengan munculnya pemain-pemain baru yang ikut mewarnai dan mendorong pengembangan filantropi. Salah satunya adalah media massa. Media massa muncul sebagai institusi efektif dalam menggerakkan kepedulian dan kedermawanan masyarakat dan televisi, radio, serta surat kabar tidak lagi hanya berperan sebagai media informasi dan hiburan, tapi mulai memperluas kiprahnya sebagai penggalang dan penyalur dana sosial melalui program "dompet" dan "peduli". ${ }^{24}$

Program-program ini tidak hanya bermunculan pada saat terjadi bencana alam maupun sosial, tapi sebagian sudah menjadi program tetap dan reguler. Distribusi dan pemanfaatan dananya, meski sebagian besar masih untuk hal-hal yang sifatnya emergency, juga sudah meluas ke masalah pendidikan, kesehatan dan ekonomi produktif. Program penggalangan kedermawanan oleh media ini mendapatkan dukungan oleh masyarakat. Hal ini tergambar dari besarnya perolehan dana yang mereka galang dari masyarakat. Pada saat bencana Tsunami di Aceh, misalnya, PIRAC mencatat lebih dari Rp.367 milyar sumbangan berhasil digalang oleh 35 media cetak dan elektronik. Sementara jumlah media yang menggalang tercatat lebih dari 150 media. ${ }^{25}$

\footnotetext{
${ }^{24}$ https://www.academia.edu, diakses, 4 Juni 2015.

${ }^{25} \mathrm{http}: / /$ pirac.org, diakses, 2 Juni 2015.
} 
Masifnya kemampuan televisi untuk mengumpulkan dana public bisa dilihat ketika peristiwa Tsunami di Aceh tahun 2004 lalu. Peristiwa tersebut diliput secara terus menerus oleh salah satu stasiun televisi, yakni Metro TV. Ketika itu Metro TV berhasil mengumpulkan dana hingga 40 milyar rupiah melalui program "Indonesia Menangis". Penggalangan dana seperti ini tidak hanya dilakukan oleh Metro TV saja. Saat ini hampir setiap stasiun televisi yang bersiaran nasional memiliki program penggalangan dana. RCTI memiliki "Jalinan Kasih", yaitu program yang memfokuskan pada pengumpulan dana bagi pengobatan mereka yang menderita. Hal serupa dilakukan oleh Indosiar dengan program "Peduli Kasih". Di TV One memiliki program acara "Satu Untuk Negeri", sedangkan di ANTV program "Yayasan ANTV Peduli Untuk Negeri". Adapun di kelompok MNC terdapat program "Beasiswa Obsesi" dan "Global TV peduli" di Global TV, "RCTI Peduli" di RCTI, serta "MNC TV Peduli" di MNC TV. Yang terakhir adalah program “Trans 7 Peduli" di Trans 7.

Di satu sisi, media massa televisi memiliki fungsi sebagai pusat informasi yang sangat strategis bagi pengumpulan dana public dalam jumlah besar. Namun demikian, media massa televisi juga memiliki peran sebagai alat untuk melakukan sosial kontrol terhadap berbagai kegiatan penggalangan dana publik. Pada saat media massa televisi telah memiliki peran ganda, tidak hanya sebagai pemberi informasi namun juga sebagai pelaku kegiatan filantropi, maka dikhawatirkan akan memunculkan persoalan obyektivitas dan independensi dari media massa televisi.Seharusnya dilematis persoalan ini tidak terjadi seandainya media massa televisi tetap berada pada tugas dan fungsi utamanya sebagai pemberi informasi, alat sosial kontrol, sarana pendidikan, serta sarana hiburan masyarakat. ${ }^{26}$

Keprihatinan media massa televisi terhadap masyarakat yang tertimpa musibah bencana alam sesungguhnya masih bisa dilakukan dengan memberikan informasi yang seutuhnya bagi masyarakat luas tentang kegiatan penggalangan dana yang dilakukan oleh lembaga-lembaga sosial yang concern terhadap musibah tersebut.

\footnotetext{
${ }^{26}$ Pasal 13 UU No.40 Tahun 1999 tentang Pers.
} 
Dengan kata lain, media massa televisi cukup menjadi fasilitator dalam memberikan berbagai informasi, baik untuk lembaga-lembaga yang akan menyalurkan sumbangannya maupun bagi masyarakat yang membutuhkan bantuan tersebut. Namun sayangnya, praktik filantropi oleh media massa televisi telah terlanjur menjadi kenyataan sosial. ${ }^{27}$

Fakta inilah yang kemudian memunculkan desakan agar dibuat suatu aturan terkait dengan kegiatan filantropi yang dilakukan media massa secara keseluruhan, televisi pada khususnya. Akhirnya Dewan Pers merespon kegelisahan masyarakat terhadap perilaku filantropi media massa tersebut dengan mengeluarkan Kode Etik Filantropi Media Massa pada tahun 2013. Kode Etik Filantropi memuat beberapa prinsip dan ketentuan yang harus ditaati media dalam menggalang, mengelola dan menyalurkan sumbangan masyarakat. Misalnya, penggalangan sumbangan harus dilakukan secara sukarela, terbuka, etis, nonpartisan dan sesuai hukum yang berlaku. Media pengelola sumbangan juga harus menyediakan rekening khusus untuk menampung sumbangan masyarakat.

Media pengelola sumbangan harus membuat sistem dan prosedur pengelolaan sumbangan secara profesional dan menyampaikan laporan program dan keuangannya secara tertulis kepada publik. Kode etik juga melarang pemanfaatan dan penyalahgunaan sumbangan masyarakat untuk keperluan promosi atau program CSR perusahaan atau pemilik perusahaan. Kode etik ini disusun oleh tim perumus yang dibentuk oleh Dewan Pers dan terdiri dari perwakilan media cetak, televisi, radio dan cyber/web. Penyusunan dilakukan dengan mengacu pada pengalaman media massa dalam dalam pengelolaan sumbangan masyarakat, berbagai praktik baik, serta kasus-kasus yang terjadi di lapangan. ${ }^{28}$

Apabila dicermati secara seksama atas apa yang tengah terjadi dalam kegiatan filantropi media massa, Heychael dan Roy menyebutkan setidaknya terdapat beberapa kritikan.

\footnotetext{
${ }^{27} \mathrm{http} / / /$ nasional.tempo.co, diakses, 4 Juni 2015.

${ }^{28} \mathrm{http}: / /$ www.dewanpers.or.id, diakses, 4 Juni 2015.
} 
Pertama adalah kurangnya penghargaan kepada pemirsa yang telah menyumbang dan kuatnya pencitraan perusahaan media. Kecenderungan ini dapat dilihat ketika pelaksanaan penyaluran sumbangan, dimana stasiun televisi tidak konsisten dalam menyebutkan bahwa sumbangan yang diberikan tersebut merupakan sumbangan dari permirsa televisi dan bukan dari perusahaan televisi tersebut. Di sini seolah-olah ada upaya untuk "mengaburkan" asal-usul sumbangan tersebut yang semula dari pemirsa televisi menjadi dari perusahaan terlevisi.

Kedua, pelaku atau aktor yang memberikan sumbangan tersebut tidak ada kaitan struktural terhadap lembaga filantropi tersebut. Hal ini dapat ditemukan di beberapa televisi yang menggunakan jasa selebriti, tokoh/pejabat publik atau pemilik media massa tersebut yang sesungguhnya tidak memiliki posisi structural dalam lembaga filantropi. Selain menunjukan bergesernya peran tanggungjawab dari stasiun televisi kepada aktor/selebriti serta mengesankan tidak independennya media massa dan lebih mengedepankan unsur branding perusahaan. Hal ini juga menunjukan seolah-olah sebagai bentuk upaya media memberikan pelayanan terhadap pejabat public dengan menggunakan dana masyarakat. Tidak hanya memunculkan penyalahgunaan dana public namun juga mengurangi integritas lembaga filantropi.

Ketiga, adanya kerancuan identitas lembaga pengelola filantropi. Pada beberapa kasus televisi sering kali bekerjasama dengan berbagai pihak dalam proses penyaluran bantuan. Kerjasama ini tidak pernah dijelaskan secara baik sehingga sangat memungkinkan munculnya kerancuan. Contoh kerancuan itu dapat dilihat ketika "Pundi Amal SCTV" bekerjasama dengan SIKIB (Solidaritas Istri Kabinet Indonesia Bersatu) dalam menyalurkan bantuan untuk korban banjir Jakarta tahun 2013. Pihak manakah yang sesungguhnya yang menyumbang ? Hal inilah yang menimbulkan di masyarakat luas.

Keempat, profesionalisme, merujuk pada Kode Etik Media Massa, ukuran prinsip profesionalisme adalah adanya kajian terdahulu untuk menentukan kebutuhan public yang akan disumbang, seperti tercantum dalam Bab 3 pasal 9 ayat 2 Kode Etik Filantropi Media Massa, yakni "pengelola sumbangan masyarakat di media massa harus melakukan pengkajian (assessment) lapangan secara akurat mengenai kebutuhan, baik jumlah maupun jenis sumbangan yang dibutuhkan penerima manfaat". 
Persoalan profesionalisme yang kerap terabaikan secara teknis akan berimplikasi terhadap pelanggaran etika. Sebagai contoh dapat dilihat pada saat tidak konsistennya penyebutan pemirsa sebagai pihak yang memberikan sumbangan, lalu tidak jelasnya tujuan dan sasaran program, dan peranan stasiun hanya sebatas menjadi perantara. Kemudian hal penting lainnya adalah tidak tepatnya bantuan yang diberikan.Semua ini disebabkan karena stasiun televisi tidak memiliki pengalaman sebagai lembaga filantropi yang professional. Pada akhirnya pengelolaan dana sumbangan dari pemirsa televisi dikelola oleh para pekerja media yang mendadak menjadi pekerja filantropi.

Kelima, tidak disebutkannya nominal sumbangan yang diserahkan. Modus umum penyaluran sumbangan oleh televisi hanya menyebutkan jumlah dan jenis barang yang disalurkan tanpa menyebutkan besaran dana. Seharusnya penyebutan akan jumlah dana yang disumbangkan akan sangat penting bagi masyarakat yang telah menyumbang untuk mengetahui seberapa besar dana yang disumbangkan oleh media massa tersebut. Hal ini menunjukan masih lemahnya penerapan asas transparansi dan akuntabilitas organisasi filantropi sehingga menyebabkan sulitnya masyarakat untuk melakukan verifikasi.

Keenam, tiadanya pelaporan dana. Dalam pelaksanaan di lapangan tidak satu pun stasiun televisi yang menyiarkan secara lengkap dan berkala atas dana yang terkumpul dan tersalurkan. Inilah titik paling krusial, yakni transparansi yang menjadi titik pokok dalammembangun kepercayaan antara public dan perusahaan media. Seharusnya, ketika promosi program penggalangan dana dilakukan melalui media televisi, maka laporannya pun tidak cukup hanya tertulis saja, namun juga dipublikasikan di media televisi . Oleh karenanya akan tercipta keseimbangan antara promosi program dan pertanggungjawaban program.

Kegagalan perusahaan media massa televisi memahami frekuensi sebagai milik public. Sebagai milik public tentunya frekuensi yang dipinjamkan ke perusahaan haruslah berdampak baik bagi kepentingan public. Di sisi lain penggunaan frekuensi untuk kepentingan pencitraan perusahaan dan pemilik menjadi bukti adanya penyalahgunaan fungsi frekuensi. Tanggung jawab perusahaan media massa, khususnya televisi, seyogyanya tidak hanya kepada pemirsa namun juga kepada seluruh masyarakat, sehingga transparansi dan akuntabilitas dapat terjaga. 


\section{Penutup}

Adanya dualisme tugas dan fungsi dalam perusahaan media massa, yang tidak hanya sebagai pemberi informasi namun juga sebagai lembaga filantropi, merupakan "akibat" dari munculnya iklim kebebasan di Indonesia sehingga semua elemen masyarakat dapat berperan sebagai lembaga filantropi. Hal-hal seperti ini seakan menjadi penguat bahwa dalam persoalan perkembangan filantropi, kelompok masyarakat sipil sangat berperan sehingga memunculkan kesan negara tidak terlalu mencampuri persoalan tersebut.

Di sisi lain kemajuan perkembangan di dunia filantropi Indonesia, yang pada dekade 90-an memunculkan lembagalembaga baru, khususnya lembaga filantropi media massa, menjadi fenomena baru yang harus dicermati. Keberadaan Kode Etik Filantropi Media Massa diharapkan mampu menjadi pemandu agar tujuan serta fungsi lembaga filantropi tetap pada jalurnya. Di lain sisi peranan media massa sebagai pilar demokrasi pun tetap kokoh.

Faktor keyakinan dalam agama menjadi pendorong utama bagi masyarakat Indonesia, khususnya Islam, dalam melakukan berbagai kegiatan berderma untuk kemaslahatan bersama. 


\section{Daftar Pustaka}

Al-Haurani, Yasir Abdul Karim, al-Waqf wa al-'Amal al- Ahli fi al-Mujtama' al-Islami Case: Jordan, Kuwait, Kuwait Awqaf Public Foundation, 2001.

Anheier, Helmut K dan Regina A.List, A Dictionary of Civil Society, Philanthropy and the Non-Profit Sector, London-New York: Routledge:2005.

Azra, Azyumardi, "Filantropi dalam Sejarah Islam di Indonesia", dalam Zakat dan Peran Negara, ed. Kuntarno Noor Afiah dan Mohd, Nasir Tajang, Jakarta: Forum Zakat, 2006.

Badan Wakaf Indonesia,KAPF, IRTI, Manajemen Wakaf di Era Modern,(Jakarta: Badan Wakaf Indonesia, 2013.

Direktorat Jenderal Bimbingan Masyarakat Islam dan Penyelenggaraan Haji, Pedoman Pengelolaan \& Pengembangan Wakaf, Jakarta: Dirjen Bimas Haji, 2003.

Fauzia, A, Faith and the State: A History of Islamic philanthropy in Indonesia. ASEAS - Austrian Journal of South-East Asian Studies, 6 (2), 2013.

Fauzia, Amelia, dan Ary Hermawan, "Ketegangan Antara Kekuasaan dan Aspek Normatif Filantropi Dalam Sejarah Islam Indonesia", Dalam Buku Berderma Untuk Semua, Jakarta: Mizan, t.t.

Ibrahim, Barbara, From Charity to Social Change: Trends in Arab Philanthropy, Kairo:American University in Cairo Press, 2008.

Ibrahim, Rustam, "National Directory of Civil Society Resource Organizations: Indonesia", Jakarta: TheSynergos Institute, 2002.

Laila, Tanim, "Innovations in Islamic Philantrophy and Monetization of Islamic Philantrophic Instruments", Institute of Hazrat Mohammad Saw, t.th, 1.

Mohsin, Magda Ismail Abdel , "Financing Through Cash-Waqf:a Revitalization to Finance Different Needs", International Journal of Islamic and Middle Eastern Finance and Management, Vol. 6 No. 4, 2013.

Mughniyah, Muhammad Jawad, Fiqih Lima Mazhab, Jakarta: Lentera, 2008. 
|Muhammad Aiz

Nofianti, Eka, V, Indah Sri Pinasti, Puji Lestari, "Kohesi Sosial dalam Tradisi Jimpitan Beras pada Masyarakat Perdesaan (Studi Kasus Di RT 01 RW 02 Desa Kemiri Lor, Kecamatan Kemiri, Kabupaten Purworejo)", ESOCIETAS,Volume 3, Number 2, Tahun 2014.

Prihatna, Andi Agung, "Filantropi dan Keadilan Sosial di Indonesia". dalam Chaider S. Bamualim dan Irfan Abubakar. Revitalisasi Filantropi Islam: Studi Kasus Lembaga Zakat dan Wakaf di Indonesia, Jakarta, CSRC, 2007.

Risdianto, Kebebasan Bermazhab Dalam Hukum Islam: Studi Terhadap UU No.41/2004 tentang Wakaf, Disertasi UIN Syarif Hadiyatullah Jakarta, 2014.

Saidin, OK, Aspek Hukum Kekayaan Intelektual, Jakarta: Raja Grafindo Persada, 2003.

Sumardhani, R. H, "Revitalisasi Semangat Ethnic Philanthropy", Humanitas, Vol. 1 No.1, Juli-Desember 2008.

Undang-Undang

UU No.40 Tahun 1999 tentang Pers

Zaim, Saidi, Mohammad Fuad dan Hamid Abidin, Praktik Filantropi Keadilan Sosial di Indonesia: Studi kasus lima CSRO (Civil Society Resource Organization), Jakarta: PIRAC, 2006. 